\title{
THE BATTLE OF MĂRĂȘEȘTI. THE STORY OF A MAUSOLEUM
}

\author{
Luminița Elena Vasiliu ${ }^{1}$ \\ University Valahia of Targoviște
}

\begin{abstract}
Located in the "fire triangle" Mărăști, Mărășești, Oituz, the battle of Mărășești represents the most important battle of the first World War on the Romanian front.

The battle from Mărășești, which lasted 29 days (24 July/6 August to 21 August/3 September 1917), stands for an important page of military history, being dubbed the "Romanian Verdune". The Romanian army, although exceeded both in number and in the first technical means of fighting, managed, by tactics and by galvanizing the soldiers, to frustrate the offensive plans of the "frontier breaker", Anton Ludwig August von Mackensen.

Right on the ground where the battle had taken place, the Mausoleum of the First World War Heroes was built. The remains of over 5,000 soldiers and officers are buried there.

This paper aims to bring back to the image of today's generation the brilliant victory of the Romananian army.
\end{abstract}

Keywords: First World War; Mărășești; Ecaterina Teodoroiu; Mausoleum; Eremia Grigorescu.

\section{INTRODUCTION}

Mărășești, managed to crush the plans of the Central Powers to get Romania out of war. Engaged in an overwhelming war, the Romanian army, made up of peasants and led by skilled commanders, managed to cope with an enemy who had both numerical superiority and the most modern technical means.

The reorganization of the Romanian army in the winter of 1916 and spring of 1917 was carried out under very difficult conditions.A large part of population from the Southern part of the country took refuge in Moldavia. The Russian troops, who had a staff of about a million people, were also brought here. Thus, in a few weeks, the population of Moldova has tripled. The difficult living conditions represented by the lack of clothing and food, led to exantematic typhos and recurrent fever epidemics, which hit both the civilian population and the military.

\section{THE BEGINNING}

After the battle in Mărăști, ending with the success of the Romanian army, the German army reorganizes, giving up the offensive in the Namoloasa area. It forces the entry into Moldova, through the Mărășești and Oituz points, aiming to pullout the Romanian army from the war and to have a free way to enter Ukraine.

In the summer of 1917, the front settled on the Galati-Nămoloasa-Tecuci-Mărășești-MărăștiOituz line. Although the force ratio was superior to the enemy, the Russian-Romanian army had, in the Mărășești area, a well-designed defense system by general Christescu. The system develops in length on the Cosmești-Muncelu line and in width, in rows defense trenches.

At Mărășești there were four rows of trenches, spread over a width of 4-5 kilometers. In the middle of it is the railway knot at Mărășești and the bridge at Cosmești. The bridge was of particular importance, facilitating the passage of German troops to southern Ukraine.

The battle was conducted along three lines:

\footnotetext{
${ }^{1}$ Corresponding author: vasiliuluminita@yahoo.com
} 
1. Toward Siret;

2. Front on Mărășești;

3. The counterattack from Răzoare Forest, Muncelu, Cota 100.

The length of the front was about 35 kilometers. There were numerous forces present in this area: The Russian 4th Army ( 84 battalions) and the Romanian first Army (6 divisions, including a cavalry division, an aeronautics group division and a heavy artillery division).

The German forces in the offensive sector were consisted of 102 infantry battalions, 10 cavalry squadrons, 24 pioneering companies, 2 mini-cars, 1135 machine guns, 356 mine throwers, 223 field tunnels, 122 guns and heavy howitzer (Kirițescu, 1989,84-85).

\section{THE STAGES OF THE BATTLE}

The battle in Mărășești took place in three stages.

\section{The first stage}

The first stage started on the morning of $24 \mathrm{July} / 6$ August 1917, with an artillery barrage that lasted 2,30 hours. Mărășești was razed from the face of the earth. Three German divisions, 12th Division, 76 and 89 Infantry Division attacked Mărășești Frontal, on a $10 \mathrm{~km}$ sector between Siret and Focsani- Mărășești railway. This sector was defended by the Russian 34 Infantry Division, in which General Christescu sent the Romanian 5th Infantry Division. The latter gets into the defence system and stops the German advance, preventing the enemy from reaching the bridge at Cosmesti.

The next day, von Mackensen, attacks northwards, perpendicularly to the front, in the area of Doaga- Mărășești. It is causing the Russian-Romanian troops abandoning the village of Doaga.The 34th Russian Division was decimated. The German army used a hollow with chlorine gas. Almost all the horses used to tow the heavy cannons of the Russian 34 Division died asphyxiated and they were abandoned.

The Russian 71 infantry Division, the Romanian 14 and 9 Infantry Divisions receive orders and enter the device to cover the remains of the Russian 34 Division and to stop the advance of the German army on the Doaga-Mărășești sector. Romanian soldiers showed great heroism in hand-tohand fighting.( Actualitatea, no.13-14, 1921, 4-8)

On 27 July/9 August the whole fight was moved to the flow area of Siret. The Roman 5th and 9th divisions in the area of Siret are retreating to the north of the railway Tecuci- Mărășești. From lasi, from the Romanian-Russian united command led by Scerbaciov, orders are given for a counteroffensive on the entire front area. This counteroffensive starts on 28 July/10 August. Despite the hard fighting, Russian-Romanian troops were unable to recover the village of Doaga. In regiments 5 and 9 Romanian infantry and in regiments 13 and 71 Russian infantry there are massive losses (Dabija 1936, 506).

General Ragoza and general Christescu are to be put under pressure following the failure. While Christescu wanted an offensive action, general Ragoza wanted to withdraw from Sascut. Following these disagreements, general Christescu is replaced, and he is sent to inspect conscripts from Moldova (loanițiu 1929,330).

After the war, Christescu was declared by communist history as the traditional model of cowardness, as a traitor of the Russians, and was banned from burial in the Mausoleum in Mărășesti.

General Eremia Grigorescu was brought to the leadership of the first Romanian Army under pressure from landlord Negropontes. A command is created under the leadership of Russian General Ragoza.

As of 29 July/11 August 1917, the intensity of the battle around Mărășești has decreased.

\section{The second stage}

The second stage was the beginning of a German offensive in the Panciu-Muncelu area. The Russians are withdrawing from the line, and General Ragoza is asking the command of Romanian troops to withdraw. This is where the conflict between generals Grigorescu and Ragoza comes from. 
This withdrawal meant the loss of Marasesti locality and the alignment of troops on the Adjud line. Ragoza is dismissed, and the command of the Romanian-Russian troops lies with General Eremia Grigorescu (Actualitatea no 18-19, 1921, 1-5)

On 1/14 August 1917, von Mackensen gave orders to attack the Chicera, with the German army advancing on the front area 10 kilometers. There is a danger of the front breaking and of the German troops entering, surrounding the Romanian-Russian troops in the Mărășești area.

The Germans at the same time strongly attack the position of the Cosmești bridge. The Romanian troops could not resist and are retreating in the area of Nicorești. They decided that the bridge should be dynamited so that it would not fall into the hands of the enemy.

On 6/19 August 1917, a generalized attack begins on the whole front line, the climax of the fighting in Mărășești. The 5th German infantry Division hits the front hard between Panciu and Mărășești, in the area of the Răzoare Forest and the Cota 100.

The front situation is represented in Fig. 1.

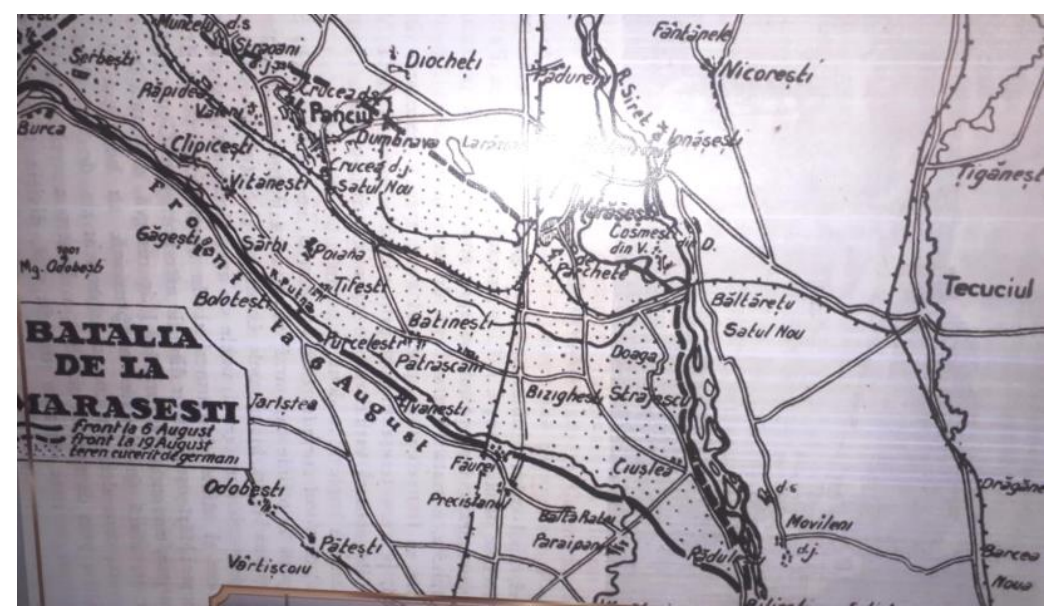

Figure 1. State of the front on 6 and 9 August 1917

Source: The Vrancea Museum, The Mausoleum Marasesti

Captain Grigore Ignat dies here. The actions stopped the German army from moving forward until reserves came. The Germans have not managed to break the front.

There were fierce battles in the Mărășești railway station area. The railway station and the railway were destroyed.

In the no. 90 Order of the day, General Eremia Grigorescu (Fig. 2) addresses the Romanian soldiers: "...you have ruined the terrible efforts of the wild enemy, proving the world more than once that there's no way of passing through here. There's where the German General Mackensen has seen what defeat means.

Mărășești has been the tomb of the German illusions. (Munteanu, 1977, 97-98).

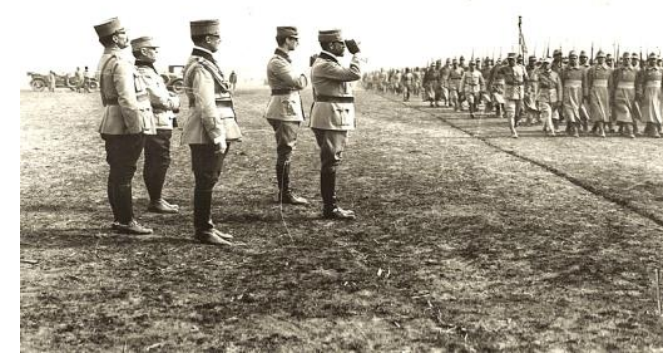

Figure 2. General Eremia Grigorescu

Source: The Vrancea Museum, The Mausoleum Marasesti. 


\section{The third stage}

Phase three took place from 7/20 August to 21 August/3 September 1917 and was characterized by a weakening of the intensity of the fighting. The Germans focused on strengthening positions in the Varnita-Muncelu area, trying another massive attack (Actualitatea no 21-22,1921,5-7)

On 15/28 August, the German IX Army launches its last offensive. The artillery opens fire on the Mărășești -Varnita line. Early in the day, the Germans are strongly attacking in the workers' area, the Russians are retreating to the north, two Russian regiments are deserting, with the remaining empty position being immediately occupied by the Romanian 3rd Infantry Division.

On 16/29 August the Romanian 9 and 13 Divisions and the Russian 15 Division are brought from the Doaga- Cosmești area to the Muncelu area in order to recover the lost land. Ecaterina Teodoroiu also dies here, headed by an infantry platoon. In the no. 1 Order of the day 23rd August 1917, Ecaterina Teodoroiu in called "The Heroine from Jiu" (Fig.3).

From the stories heard from the villagers of Fitionești village, we find that the place where the heroine died is in a clearing in the north of the Fitionești village. Severely wounded she was taken to the field hospital where she died. She was buried in Fitionești, District of Putna, her remains being later moved to $\mathrm{Tg}$. Jiu, in a mausoleum in the city centre.

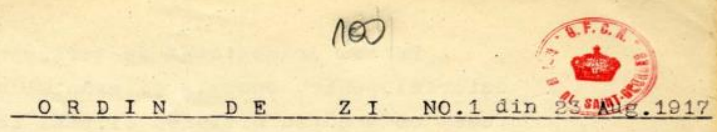

In timpul eioenirei de eri noaptea pe Dealul Secului a cărut in fruntea plutonului său lovită in inimă-i generoasă, de dour gloanet de mitralieră, Voluntara Ecaterina Teodoroiu, ain compania 7-a.

Piláa rară a unui cald entusiasm unit cu cea mai stăruitoare energie,aceia pe care uni au numit-o cu arept cuvant Eroina dela Jiu, si-a dat jertfá supremă,lipsitr de orice trufie, de orice desearta ambitie, numai din aragostea de a apara pămantul tarei acesteia cotropitá de dusmani.

Eeaterina Teodoroiu a fost la inätimea celor mai vitej aparătorí ai tarei sale si i-a intrecut prin puterea cu care Infrângâna släbiciunea femeiască a stiut sã dovedească vígoarea bărbatiei de trup si de suflet si calitatile intregi ale unui ostas Inärsnet, neobosit si plin de entusiasmul de a se face folositore cu orice pret. Aceia care a luptat ca un viteaz din alte vremuri la Târgu Jiu, aceia care si-a desfúsurat energia-1 rară, Impotriva "mortei albe $"$ care a secerat pe camarazil ei bolnavi de tifos exantematic, pornise din nou la lupta cu avant renascut, ou núdejdea că va contribui si ea la opera cea mare a revansei la a carei pregătire a luat parte foarte activá, conducând instructia.-

A carut Inainte de ajunge 1 a Si-a dat viata cu simplitatea eroismului adevarat, nu pentru

a obtine apoteze de vorbe ci pentru cá asa credea sufletul ei ca se implineste datoria vietei. Aceia care In vitejia-i comunicativa a murit in clipa eand se deseoperea spre a-si Indemna ostasii cu vorbele: "Inainte breti, nu vă lăsati, sunteti cu mine !" are arept ain clipa aceasta la cinstirea vesnica a unui nume neuitat de camarazi.

Figure 3. Documents about death of Ecaterina Tedoroiu

Source: National Library of Romania- Digital Library: http://virtual1.bibnat.ro/arhiva\%20istorica/Fond\%20Saint\%20Georges/dosar938/Fond\%20Saint\%20Georges-dosar\%20938-fila\%2098-103_005.jpg 
Another heroic story is that of Măriuca Zaharia, a 12 year old girl, who, from up a tree kept providing useful information about the position of the german troops till she was shot to death.

On 20 August/3 September, given the massive effort and the fact that the troops were exhausted, both sides decided to stop the fight and to preserve every place they took as a result of the fighting (Kiritescu 1989, 177).

This is how the event known in German historiography as "the battle of penetration at Putna and Sușita" ended (Vulcănescu 1938, 923).

\section{CONCLUSIONS}

Losses are massive in both sides. There were 27.410 injured and missing deaths in the Romanian camp, the 4th Russian Army recorded 25.650 wounded and missing deaths. The opposing camp recorded 60.000-65.000 dead, wounded and missing.

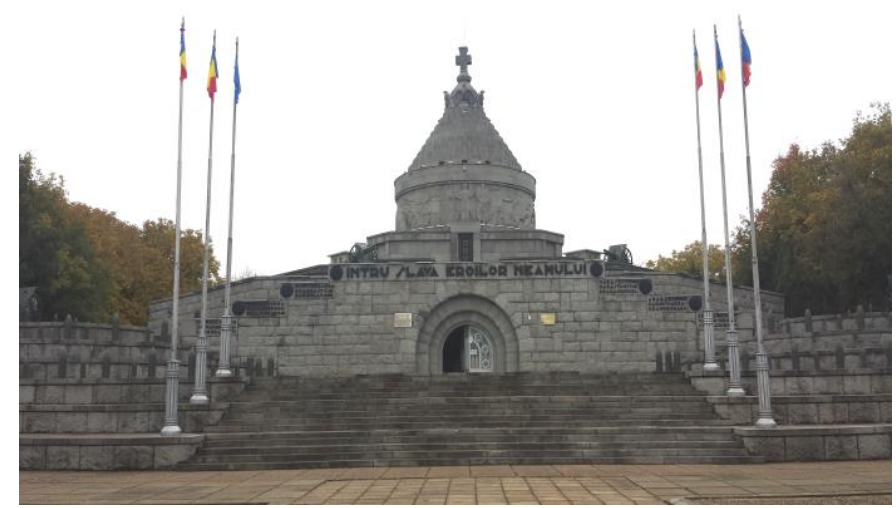

Fig. 3: The Mausoleum of the First World War Heroes

Source: The Vrancea Museum, The Mausoleum Marasesti.

The heroism of the Romanian "opincars" had a great echo in the newspapers of the weather. Thus, several Allies' publications take over the article of the "Times" press correspondent to the Romanian Army. The heroic feats of these peasant-soldiers on the battlefield were praised as they faced an army which strongly outnumbered them, being by far better equipped.

The mausoleum built in memory of the heroes at Mărăşeşti (Fig. 3) right on the former battle field, on the land donated by Ulise Negropontes on the 14th July 1921, in now known as The Church of the Romanian People. It shelters the remains of 5,073 soldiers and officers, in 154 individual vaults and 9 common ones. There also is a vault of the young heroine, Măriuca Zaharia.(Bălescu,1993,77).

In the central part there is the sarcophagus of general Eremia Grigorescu. On the front of the building there is the inscription "to the glory of the heroes of the nation, framed by the localities in which the great battles were fought during the summer of fire Jiu - Olt - Sibiu - Coşna - Cireşoaia Robăneşti - Neajlov - Dragoslave - Predeal - C. Lung - Panciu - Răzoare - Braşov - Porumbacu Mărăşeşti - Mărăşti - Oituz - Doaga - Muncel - Arabagi - Barcut - Amzacea - Prunaru - Cerna Caşin - Valea Uzului - Sticlărie (Bălescu,1993,84).

On the right of the Mausoleum there is The Museum of Battles or The Museum of Arms, where among other exhibits as arms, documents, photos, military equipment, personal objects belonging to Ecaterina Teodoroiu, a symbolic figure of the war, are to be found. 


\section{REFERENCES}

Actualitatea. 1921, no.15-22. Bucharest. Eminescu S.A. Publishing.Accessed March 5, 2021. http://digitool.bibnat.ro/R/7QDAE7EHL9ANM3YRHPR473GAQ1D22SHQUTTEBTE7M3YRJXG R8X-02366? func=results-jump-full\&set_entry $=000004 \&$ set_number $=000015 \&$ base $=$ GEN 01

Bălescu, Valeria. 1993. The mausoleum from Mărăşeşti. Bucharest: Military Publishing House.

Cupşa, Ion. 1967. Mărăști, Mărăşeşti, Oituz, Bucharest: Military Publishing House.

Dabija, Gheorghe. 1936. Romanian Army in World War (1916-1919). Bucharest: Lupta-N. Stroilă Printing House. Vol.4. Accessed March 7, 2021. http://dspace.bcucluj.ro/ handle/123456789/82032

Ioanițiu, Alexandru. 1929. The War of Romania (1916-1919). Bucharest: Geniului Printing House. Vol.2. Accessed March 2, 2021. http://dspace.bcucluj.ro/jspui/handle/123456789/82516

Kirițescu, Constantin. 1989. The History of the War for the Unification of Romania. 1916-1919. Bucharest: Scientific and Encyclopedic Publishing House. Vol. 2, Accessed March 3,2021. https://msbook.pro/istorie/1713-istoria-rzboiului-pentru-intregirea-neamului-vol2-de-constantinkiritescu-pdf.html

Munteanu, R. Cassian. 1977. The Battle of Mărăşeşti. Timisoara: Facla Publishing House.

Vulcănescu, Mircea. 1938. The War for the Unification of the Nation, Bucharest: Official Gazette and State Printing. Accessed March 6, 2021. https://sas.unibuc.ro/storage/downloads/altele31/razboiul-intregirea-neamului.pdf 